\title{
Pemodelan Variasi Nilai Percepatan Gravitasi di Daerah Khatulistiwa dengan Menggunakan Metode Gauss-Newton

\author{
Suwantia, Joko Sampurno ${ }^{a^{*}}$, Azrul Azwara
}

aProdi Fisika, FMIPA Universitas Tanjungpura, Jalan Prof. Dr. Hadari Nawawi, Pontianak, Indonesia

* Email: jokosampurno@physics.untan.ac.id

\begin{abstract}
Abstrak
Telah dilakukan penelitian tentang pemodelan variasi nilai percepatan gravitasi yang bertujuan untuk memberikan gambaran variasi nilai percepatan gravitasi terhadap waktu di daerah khatulistiwa dengan menggunakan metode Gauss-Newton. Dengan menggunakan data dari percobaan bandul sederhana di daerah pengamatan yang terletak pada koordinat $0^{\circ} 03^{\prime} 30,61^{\prime \prime} \mathrm{LS}$ dan $109^{\circ} 20^{\prime} 44,09^{\prime \prime} \mathrm{BT}$, dihasilkan periodesitas data variasi nilai percepatan gravitasi sebesar 15 hari, yang merupakan setengah dari periodesitas data jarak bumi-bulan dan fase bulan. Korelasi antara variasi nilai percepatan gravitasi dengan jarak bumi-bulan sebesar 0,38. Korelasi antara variasi nilai percepatan gravitasi dengan fase bulan sebesar 0,11. Variasi nilai percepatan gravitasi hasil pengamatan dibuat model berupa sebuah persamaan dari fungsi deret Fourier orde 8, yang bergantung terhadap waktu.
\end{abstract}

Kata Kunci: variasi nilai percepatan gravitasi, percobaan bandul sederhana, Metode Gauss-Newton

\section{Latar Belakang}

Percepatan gravitasi bumi $(g)$ atau disebut juga sebagai medan gravitasi adalah gaya gravitasi yang dilakukan bumi per satuan massa pada setiap benda. Nilai percepatan gravitasi bumi dapat diukur menggunakan beberapa metode eksperimen, salah satunya dengan bandul sederhana yang terdiri atas massa berupa bandul yang digantung pada seutas tali tidak bermassa (massa diabaikan), lalu diukur panjang tali dengan meteran dan periode dengan menentukan waktu untuk satu osilasi [1]. Pengukuran nilai percepatan gravitasi dipengaruhi oleh beberapa faktor, salah satunya efek tidal (pasang surut) yang berasal dari tarikan gravitasi benda langit yang posisinya dekat dengan bumi yaitu bulan dan matahari yang menyebabkan gaya tarik naik turun, sehingga perubahan medan gravitasi di permukaan bumi berubah secara periodik [2].

Penelitian yang telah dilakukan sebelumnya, menggunakan simulasi formasi penerbangan satelit untuk mendeteksi variasi medan gravitasi dengan rentang waktu bervariasi dari tiap jam ke variasi harian yang kemudian data tersebut digunakan untuk mengestimasi medan gravitasi dengan variasi bulanan [3]. Penelitian dengan menggunakan 4,5 tahun data dari delapan superconducting gravimeters (SGs) yang dihubungkan dengan Global Geodynamics Project (GPP) dari tahun 1997 sampai dengan 2001 dilakukan untuk mensimulasikan variasi waktu medan gravitasi di Eropa yang mungkin terlihat oleh satelit [4]. Sedangkan, pada penelitian ini, penulis meneliti variasi nilai percepatan gravitasi terhadap waktu yang terjadi di daerah khatulistiwa dengan menggunakan bantuan percobaan bandul sederhana dan kemudian memodelkan hasil penelitian tersebut dengan menggunakan metode Gauss-Newton. Model ini diharapkan dapat memberikan gambaran variasi nilai percepatan gravitasi terhadap waktu di daerah khatulistiwa.

\section{Metodologi Data}

Data yang digunakan pada penelitian ini merupakan data primer yang berasal dari percobaan bandul sederhana. Data diambil setiap hari pukul 18.00 WIB selama 3 bulan. Pengambilan data difokuskan pada satu titik daerah pengamatan, yang berada pada koordinat $0^{\circ} 03^{\prime} 30,61^{\prime \prime} \mathrm{LS}$ dan $109^{\circ} 20^{\prime} 44,09^{\prime \prime} \mathrm{BT}$.

\section{Akuisisi Data}

Pengukuran nilai percepatan gravitasi dilakukan dengan bantuan rangkaian bandul sederhana. Rangkaian bandul sederhana menggunakan bandul berupa bola besi yang memiliki massa $1 \mathrm{~kg}$, tali sepanjang 2,5 m, dan sudut simpangan yang sangat kecil $\left(\theta=4^{\circ}\right)$ sehingga $\sin \theta \approx \theta$, yang digantungkan pada langit-langit ruang pengamatan. Setiap satu kali pengamatan dilakukan pengukuran berulang sebanyak 8 kali percobaan, dimana satu kali percobaan yang diukur adalah waktu $(t)$ yang diperlukan bandul untuk melakukan 20 kali ayunan. Satu kali pengamatan didapatkan 8 data pengamatan, kemudian setiap data pengamatan dicari nilai rata-rata satu kali percobaan dan didapatkan periode ayunan bandul sederhana (T). Dari data periode ayunan bandul sederhana $(T)$ dapat dihitung nilai percepatan gravitasi $(g)$ 
setiap percobaan dengan menggunakan persamaan (1), dan didapatkan nilai rata-rata percepatan gravitasi $(g)$ dari hasil perhitungan, yang mewakili nilai percepatan gravitasi $(g)$ pada hari tersebut. Pengambilan data dilakukan setiap hari, selama 3 bulan sehingga terkumpul 92 data pengamatan nilai percepatan gravitasi. Persamaan untuk menghitung percepatan gravitasi bumi yaitu sebagai berikut [1]:

$$
g=\frac{4 \pi^{2}}{T^{2}} L
$$

dengan $g \quad$ percepatan gravitasi bumi

$T \quad=$ periode ayunan bandul

$L \quad=$ panjang tali

\section{Pengolahan Data \\ Penentuan Periodesitas}

Penentuan periodesitas dilakukan dengan menggunakan metode FFT (Fast Fourier Transform), untuk mengetahui periode yang dominan. Periodesitas yang ditentukan dalam penelitian ini adalah periodesitas dari data nilai percepatan gravitasi, data jarak bumi dengan bulan dan data fase bulan [5], yang kemudian dibandingkan nilai periodesitas dari ketiga data tersebut untuk mengetahui hubungan antara ketiga data tersebut.

\section{Penentuan Fungsi Forward Modelling}

Pencocokan kurva bertujuan untuk melakukan pendekatan fungsi matematika yang dapat mewakili nilai percepatan gravitasi di daerah pengamatan dan mengetahui parameter awal (Initial Value) untuk membuat model baru. Program yang digunakan untuk pencocokan kurva adalah cftool (Curve Fitting Tool). Fungsi matematika yang digunakan dalam penelitian ini adalah fungsi deret Fourier. Bentuk umum fungsi deret Fourier adalah [6;7]:

$$
f(x)=a_{0}+\sum_{i=1}^{n} a_{i} \cos (n w x)+b_{i} \sin (n w x)
$$

dengan $n \quad$ jumlah data

$a_{0}, a_{i}, b_{i}, w=$ parameter model

$$
x=\text { hari }
$$

\section{Estimasi Variasi Nilai Percepatan Gravitasi}

Estimasi nilai percepatan gravitasi di daerah khatulistiwa ini akan dihitung dengan metode Gauss-Newton. Pada proses estimasi, initial value yang ditentukan dimasukkan ke dalam fungsi matematika yang terpilih untuk menghasilkan model baru yang dapat mewakili data observasi gravitasi. Untuk mendapatkan model yang dapat dijadikan solusi optimum, perlu dilakukan modifikasi parameter model yang dilakukan secara iteratif. Hubungan antara model $n$ yang diberikan perturbasi, dengan model pada iterasi ke- $(n+1)$ dinyatakan dalam persamaan berikut [8] :

$$
\begin{aligned}
m_{n+1}=m_{n}- & {\left[\underline{J}_{n}{ }^{T} \underline{J}_{n}\right]^{-1} \underline{J}_{n}{ }^{T}\left(g\left(m_{n}\right)-d\right) } \\
\text { dengan } m & =\text { model } \\
n & =\text { jumlah data } \\
J & =\text { matriks Jacobi } \\
d & =\text { data observasi } \\
g\left(m_{n}\right) & =\text { data kalkulasi }
\end{aligned}
$$

Solusi optimum harus memenuhi salah satu syarat konvergensi, yaitu tercapainya nilai $R M S$ error (root mean square error) atau kesalahan rata-rata yang minimum. RMS error merupakan akar dari jumlah selisih antara data kalkulasi dengan data observasi dibagi dengan jumlah data, yang dituliskan pada persamaan (4) [8]:

$$
R M S \text { error }=\sqrt{\frac{\sum_{i=1}^{n}\left(d_{k a l}-d_{o b s}\right)^{2}}{n}}
$$

$$
\text { dengan } \begin{aligned}
n & =\text { jumlah data } \\
d_{k a l} & =\text { data kalkulasi } \\
d_{o b s} & =\text { data observasi }
\end{aligned}
$$

\section{Validasi Variasi Nilai Percepatan Gravitasi}

Validasi data bertujuan untuk menguji tingkat keakuratan hubungan antara model yang diperoleh dari proses estimasi dengan data validasi. Nilai interval koefisien korelasi, ditampilkan pada Tabel 1.

Tabel 1. Interprestasi koefisien korelasi.

\begin{tabular}{cc}
\hline Interval Koefisien & Tingkat Hubungan \\
\hline $0,00-0,199$ & Sangat rendah \\
$0,20-0,399$ & Rendah \\
$0,40-0,599$ & Sedang \\
$0,60-0,799$ & Kuat \\
$0,80-1,000$ & Sangat kuat \\
\hline
\end{tabular}

Sumber: Sugiyono [9]

\section{Hasil dan Pembahasan Periodesitas}

Data variasi nilai percepatan gravitasi terhadap waktu, hasil pengamatan selama 3 bulan diperlihatkan dalam bentuk grafik pada Gambar 2 . 


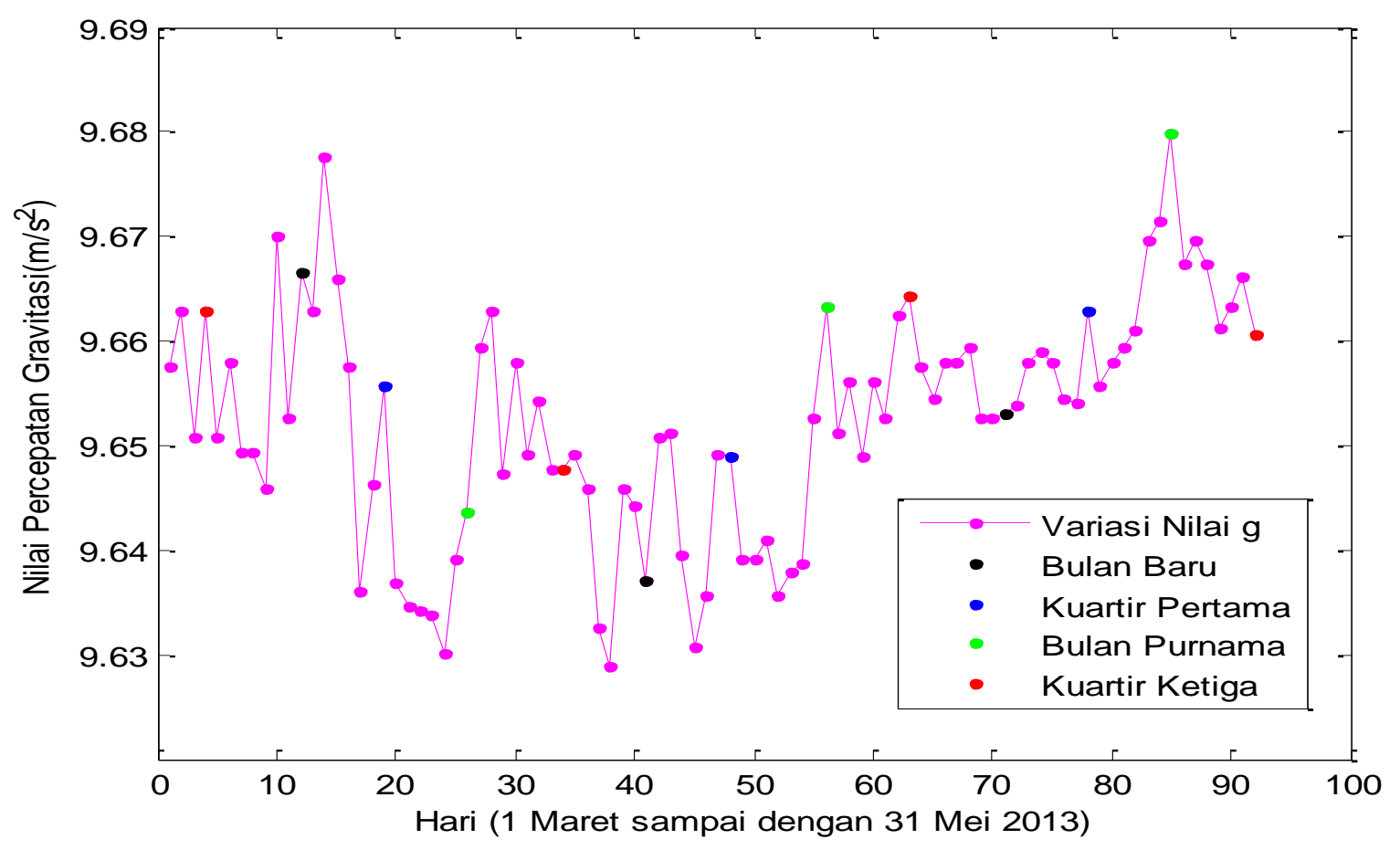

Gambar 2. Grafik data nilai percepatan gravitasi terhadap waktu.

Grafik menunjukkan adanya fluktuasi nilai percepatan gravitasi terhadap waktu. Ini dihubungkan dengan adanya pengaruh perubahan posisi benda langit yang berada dekat dengan bumi, yaitu bulan dan matahari. Namun, karena jarak matahari ke bumi cukup jauh, maka pengaruhnya sangat kecil dibandingkan dengan pengaruh bulan. Pada saat bulan baru dan bulan purnama, posisi bumi, bulan dan matahari berada pada satu garis sehingga medan gravitasi bulan dan matahari saling menguatkan yang menyebabkan nilai percepatan gravitasi bumi menjadi mengecil dan terjadi fenomena alam berupa air pasang purnama yaitu pasang dengan puncak tertinggi. Pada saat kuartir pertama dan kuartir ketiga, posisi bumi dan bulan tegak lurus terhadap matahari sehingga medan gravitasinya saling melemahkan, yang menyebabkan nilai percepatan gravitasi membesar dan terjadi fenomena alam berupa pasang perbani yaitu pasang dengan tinggi yang minimum.

Jarak bulan dengan bumi tidak tetap melainkan berfluktuasi terhadap waktu. Ini disebabkan orbit bulan ketika mengelilingi bumi tidak berbentuk lingkaran sempurna melainkan berbentuk ellips dan bidang orbit bulan ketika mengelilingi bumi membentuk sudut sebesar $5^{\circ} 11^{\prime}[10]$. Selain itu, pada waktu tertentu, posisi bulan berada sangat jauh dari bumi, atau yang disebut dengan apogee, dan di lain waktu, posisi bulan berada dekat dengan bumi, atau disebut dengan perigee. Waktu yang diperlukan bulan untuk melakukan satu periode revolusi pada orbitnya dari posisi perigee-apogee kembali ke perigee adalah 27,5 hari. Periode ini dinamakan periode anomalistik. Periode revolusi bulan pada orbitnya dari posisi fase bulan baru-kuartir pertama-bulan purnama-kuartir ketiga dan kembali ke fase bulan baru disebut periode sinodis. Waktu yang diperlukan satu periode sinodis adalah 29,5 hari. Adanya perbedaan waktu ketika bulan menyelesaikan kedua periode tersebut menyebabkan pada suatu waktu, pada fase bulan baru posisi bulan berada pada apogee, dan di lain waktu, pada fase bulan purnama posisi bulan berada pada perigee. Demikian hal yang sebaliknya juga bisa terjadi [11]. Akibatnya nilai percepatan gravitasi pada saat fase bulan baru dan bulan purnama, tidak selalu mengecil. Begitu pula pada saat kuartir pertama dan kuartir ketiga, nilai percepatan gravitasi tidak selalu membesar.

Data variasi nilai percepatan gravitasi diolah menggunakan metode FFT (Fast Fourier Transform), untuk mendapatkan nilai periodesitas percepatan gravitasi di daerah pengamatan, dalam penelitian ini yaitu daerah khatulistiwa. Nilai periodesitas menunjukkan nilai frekuensi data variasi nilai percepatan gravitasi yang paling sering muncul. 


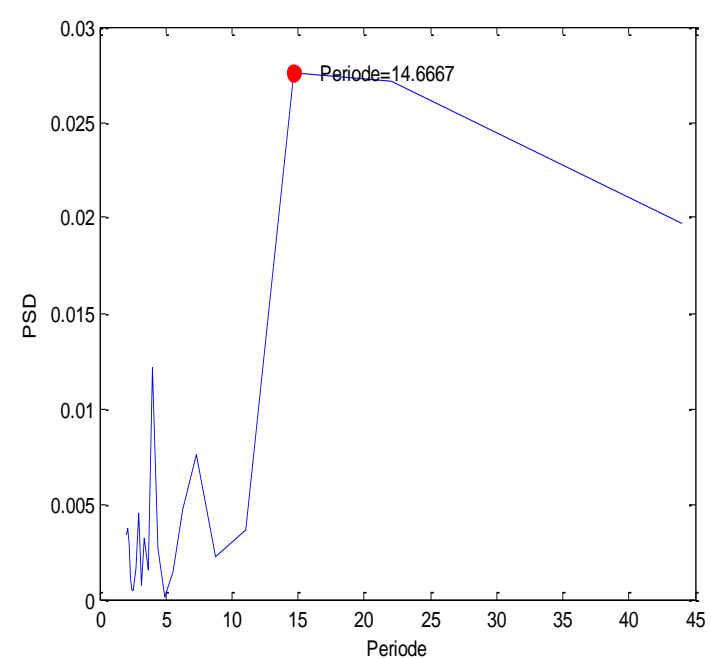

Gambar 3. Grafik periodesitas data variasi nilai percepatan gravitasi.

Periodesitas (T) data variasi nilai percepatan gravitasi adalah 15 hari, seperti yang ditunjukkan pada Gambar 3. Nilai ini menunjukkan setiap 15 hari, terdapat nilai frekuensi percepatan gravitasi yang berulang. Nilai ini juga identik dengan waktu gerak bulan, bulan melakukan satu kali revolusi dalam waktu $29,5$ hari ( $\approx 30$ hari $)$, untuk kembali ke posisi semula. Periodesitas data variasi nilai percepatan gravitasi 15 hari setara dengan setengah dari waktu satu kali revolusi bulan. Ini menunjukkan adanya pengaruh posisi bulan terhadap variasi nilai percepatan gravitasi di permukaan bumi.

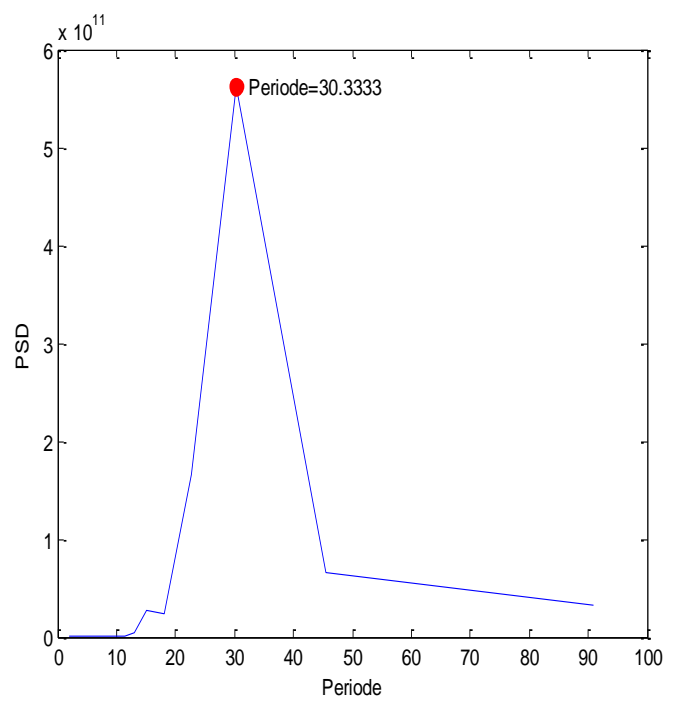

Gambar 4. Grafik periodesitas data jarak bumi dengan bulan.

Periodesitas $(T)$ jarak bumi dengan bulan adalah 30 hari, seperti yang ditunjukkan pada Gambar 4. Nilai ini menunjukkan setiap 30 hari, terjadi frekuensi jarak bumi dengan bulan yang berulang. Korelasi antara data jarak bumi dengan bulan dan data nilai percepatan gravitasi adalah - 0,38. Nilai korelasi sebesar 0,38 menunjukkan bahwa antara data jarak bumi dengan bulan dan data nilai percepatan gravitasi memiliki hubungan yang rendah. Tanda negatif menunjukkan bahwa data jarak bumi dengan bulan dan data nilai percepatan gravitasi berlawanan arah, yaitu ketika jarak bumi dengan bulan jauh, nilai percepatan gravitasi membesar dan ketika jarak bumi dengan bulan dekat, nilai percepatan gravitasi mengecil.

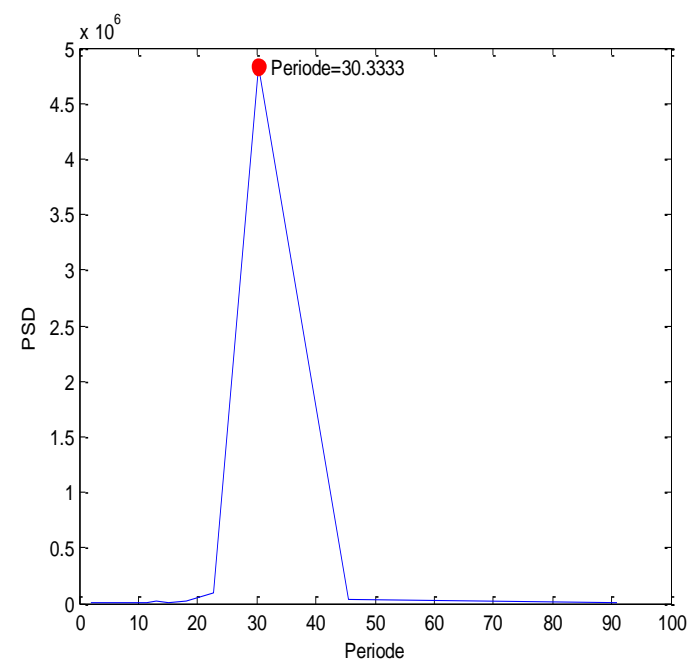

Gambar 5. Grafik periodesitas data fase bulan.

Periodesitas ( $T$ ) data fase bulan adalah 30 hari, seperti yang dtunjukkan pada Gambar 5 . Nilai ini menunjukkan setiap 30 hari, terjadi frekuensi fase bulan yang berulang. Korelasi antara data fase bulan dengan data nilai percepatan gravitasi adalah 0,11. Nilai ini menunjukkan bahwa data fase bulan dan data variasi nilai percepatan gravitasi memiliki hubungan yang sangat rendah. Periodesitas data jarak bumi dengan bulan dan data fase bulan memiliki nilai yang sama yaitu 30 hari. Periodesitas data nilai percepatan gravitasi memiliki nilai setengah dari periodesitas data jarak bumi dengan bulan dan data fase bulan, yaitu 15 hari. Ini disebabkan dalam satu periode, bulan memiliki 2 posisi yang dianggap memiliki pengaruh yang sama terhadap variasi nilai percepatan gravitasi di permukaan bumi.

\section{Pemodelan Variasi Nilai Percepatan Gravitasi}

Pemodelan diawali dengan menentukan jumlah data yang dimodelkan dengan jumlah data yang digunakan sebagai validator. Model baru didapatkan dari hasil perhitungan menggunakan tebakan awal parameter model yang diperoleh dari proses pencocokan kurva. 
Parameter model awal yang digunakan dalam pemodelan diperlihatkan pada Tabel 2.

Tabel 2. Parameter model awal.

\begin{tabular}{cc|cc}
\hline Parameter & Nilai & Parameter & Nilai \\
\hline$a 0$ & 9,653 & $a 5$ & $-0,002718$ \\
$a 1$ & 0,008295 & $b 5$ & $-0,001168$ \\
$b 1$ & $-0,006228$ & $a 6$ & 0,002084 \\
$a 2$ & $-0,0003478$ & $b 6$ & $-0,003054$ \\
$b 2$ & $-0,0002167$ & $a 7$ & 0,00319 \\
$a 3$ & 0,001581 & $b 7$ & 0,002681 \\
$b 3$ & $-0,0008528$ & $a 8$ & 0,0004728 \\
$a 4$ & $-0,004919$ & $b 8$ & 0,001684 \\
$b 4$ & 0,0003003 & $w$ & 0,06497 \\
\hline
\end{tabular}

Pemilihan jumlah data observasi dan data validasi diperoleh jumlah data observasi yang digunakan sebanyak 76 data. Data model didapatkan dari hasil perhitungan parameter model awal dengan menggunakan persamaan forward modelling yang berbentuk persamaan fourier orde ke-8. Solusi didapatkan pada iterasi ke-7, dengan nilai RMS error 0,006 yang diperlihatkan pada Gambar 6. Nilai ini memenuhi syarat konvergensi, sehingga solusi dapat diterima.

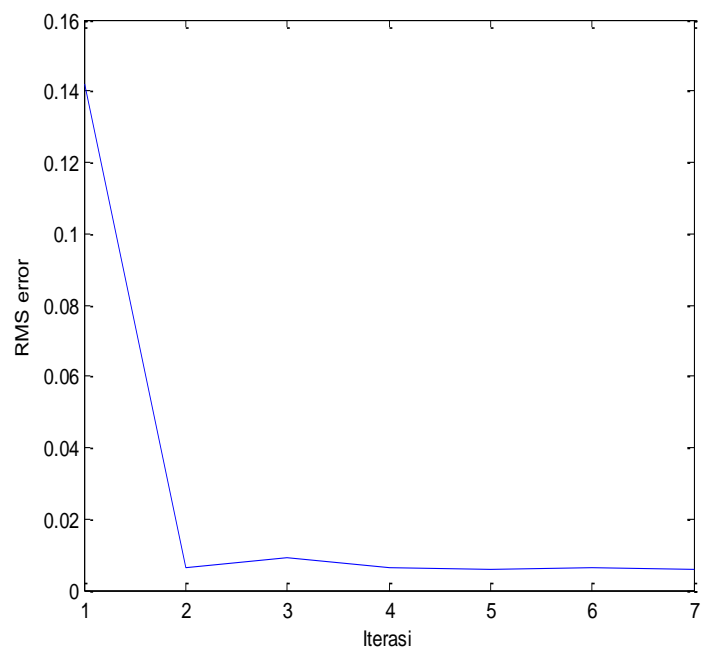

Gambar 6. Grafik perubahan nilai RMSE pada proses iterasi.

Solusi menghasilkan parameter model baru, yang diperlihatkan pada Tabel 3.

Tabel 3. Parameter model baru hasil pengolahan data.

\begin{tabular}{cc|cc}
\hline Parameter & Nilai & Parameter & Nilai \\
\hline$a 0$ & 9,6499 & $a 5$ & 0,0052 \\
$a 1$ & 0,0077 & $b 5$ & 0,0006 \\
$b 1$ & 0,0014 & $a 6$ & $-0,0003$ \\
$a 2$ & 0,0014 & $b 6$ & 0,0022 \\
$b 2$ & $-0,0013$ & $a 7$ & $-0,0001$ \\
$a 3$ & $-0,0046$ & $b 7$ & 0,0008 \\
$b 3$ & 0,0013 & $a 8$ & $-0,0006$ \\
$a 4$ & $-0,0023$ & $b 8$ & 0,0008
\end{tabular}

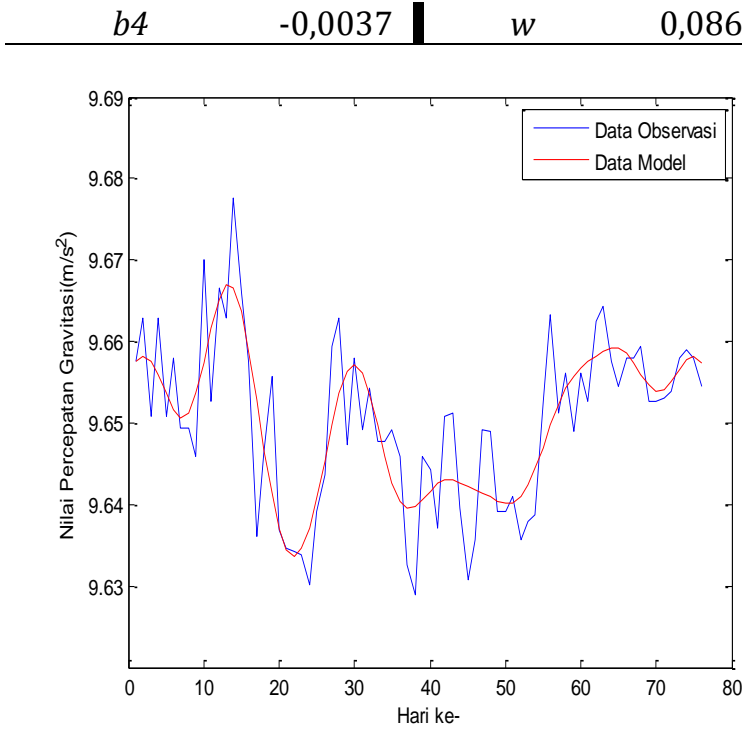

Gambar 7. Grafik perbandingan antara data observasi dengan data model nilai percepatan gravitasi.

Parameter model baru menghasilkan model matematis baru yang mendekati variasi nilai percepatan gravitasi di daerah khatulistiwa seperti yang diperlihatkan pada Gambar 7 . Model baru berbentuk persamaan, sebagaimana diperlihatkan pada persamaan (5):

$$
\begin{aligned}
& g(t)=9,6499+0,0077 * \cos (0,0863 * t) \ldots \\
& +0,0014 * \sin (0,0863 * t)+0,0014 * \cos (2 * 0,0863 * t) \ldots \\
& -0,0013 * \sin (2 * 0,0863 * t)-0,0046^{*} \cos (3 * 0,0863 * t) \ldots \\
& +0,0013 * \sin (3 * 0,0863 * t)-0,0023^{*} \cos (4 * 0,0863 * t) \ldots \\
& -0,0037 * \sin (4 * 0,0863 * t)+0,0052^{*} \cos (5 * 0,0863 * t) \ldots \\
& +0,0006 * \sin \left(5^{*} 0,0863 * t\right)-0,0003 * \cos (6 * 0,0863 * t) \ldots \\
& +0,0022^{*} \sin \left(6^{*} 0,0863 * t\right)-0,0001 * \cos (7 * 0,0863 * t) \ldots \\
& +0,0008^{*} \sin (7 * 0,0863 * t)-0,0006^{*} \cos (8 * 0,0863 * t) \ldots \\
& +0,0008^{*} \sin \left(8^{*} 0,0863 * t\right)
\end{aligned}
$$

Data model baru dikorelasi dengan data observasi, yang menghasilkan nilai korelasi 0,82. Nilai korelasi ini menunjukkan antara data model baru dengan data observasi memiliki hubungan yang sangat kuat. Sehingga model yang baru dapat mewakili data observasi.

Data validasi sebanyak 16 data digunakan untuk proses validasi data model baru, yang diperlihatkan pada Gambar 8. Setelah divalidasi, didapatkan nilai korelasi validasi sebesar 0,62. Nilai ini termasuk ke dalam rentang koefisien korelasi yang memiliki hubungan kuat. Nilai RMS error validasi sebesar 0,01, yang menunjukkan nilai kesalahan yang minimum. Model dapat diterima dan dapat mendekati gambaran variasi nilai percepatan gravitasi di 
daerah khatulistiwa untuk 16 hari ke depan seperti yang ditunjukkan pada Gambar 9.

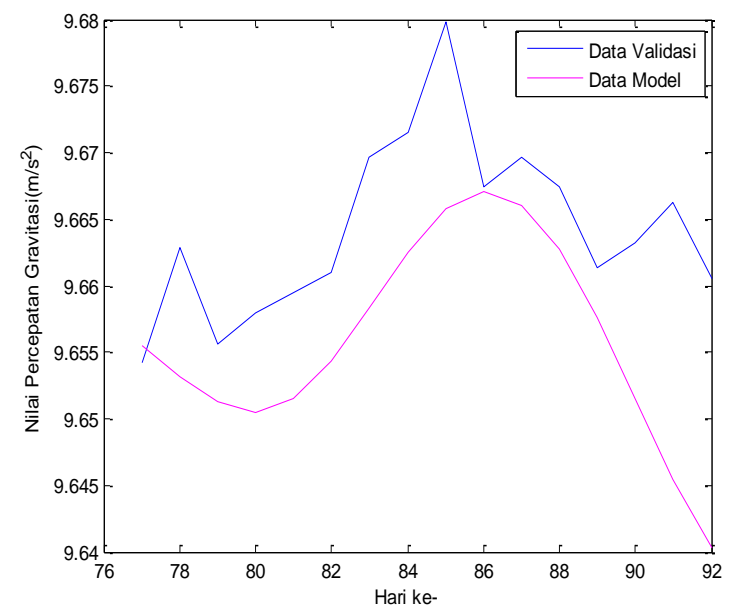

Gambar 8. Grafik validasi antara data validasi dengan data model variasi nilai percepatan gravitasi.

Prediksi variasi nilai percepatan gravitasi, diperlihatkan pada Tabel 4 .

Tabel 4. Prediksi variasi nilai percepatan gravitasi untuk 16 hari ke depan.

\begin{tabular}{cc|cc}
\hline Hari ke- & $\boldsymbol{g}$ & Hari ke- & $\boldsymbol{g}$ \\
\hline 93 & 9,6364 & 101 & 9,6544 \\
94 & 9,6342 & 102 & 9,6567 \\
95 & 9,6338 & 103 & 9,6571 \\
96 & 9,6350 & 104 & 9,6557 \\
97 & 9,6378 & 105 & 9,6527 \\
98 & 9,6417 & 106 & 9,6488 \\
99 & 9,6462 & 107 & 9,6450 \\
100 & 9,6507 & 108 & 9,6419 \\
\hline
\end{tabular}

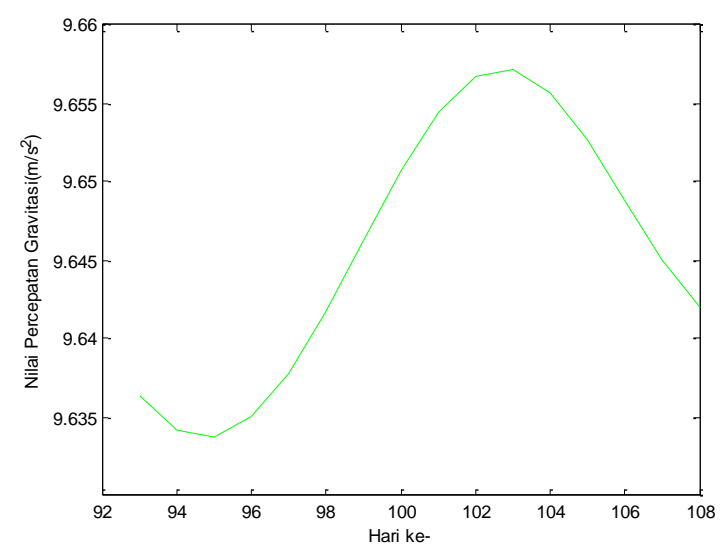

Gambar 9. Grafik prediksi nilai percepatan gravitasi untuk 16 hari ke depan.

\section{Kesimpulan}

Berdasarkan penelitian yang telah dilakukan, diperoleh kesimpulan bahwa, variasi nilai percepatan gravitasi dipengaruhi oleh jarak bumi-bulan dan fase bulan. Namun, ternyata pengaruhnya cukup kecil dimana nilai periodesitas jarak bumi-bulan dan fase bulan sebesar 30 hari, sedangkan nilai periodesitas variasi nilai percepatan gravitasi sebesar 15 hari. Dari penelitian ini juga didapatkan model yang mewakili variasi nilai percepatan gravitasi terhadap waktu berbentuk persamaan yang menggunakan fungsi deret fourier orde 8 (persamaan 5), dengan nilai korelasi validasi model sebesar 0,62 dan RMS error validasi sebesar 0,01 .

\section{Daftar Pustaka}

[1] Tipler, Paul. A., 1998, "FISIKA Untuk Sains dan Teknik", Ed ke-3, Jilid 1, Prasetio, Lea.; Adi, Rahmad W. (alih bahasa), Erlangga, Jakarta.

[2] Oktobiyanti, Riri., 2009,"Pemodelan Sistem Geothermal Daerah Sibayak Menggunakan Data Magnetotellurik dan Gravitasi", Universitas Indonesia, Program Studi Fisika, Fakultas Matematika dan Ilmu Pengetahuan Alam, Depok, (Skripsi).

[3] Elsaka, Basem Abd Elkareem Anwar., 2010, "Simulated Satellite Formation Flights for Detecting the Temporal Variations of the Earth's Gravity Field", Institut für Geodäsie und Geoinformation der Universität Bonn, Astronomisch-Physikalische und Mathematische Geodäsie, Germany, (Disertasi).

[4] Crossley, David., Hinderer, Jacques., Boy, Jean-Paul., 2005, "Variasi Waktu Medan Gravitasi Eropa dari Superconducting Gravimeters", J. Int. Geophys., 161:257-264.

[5]www.nasa.gov/audience/foreducators/topna v/materials/listbytype/Distance_Moon.html \#.VrRCi9N96Uk, diakses 5 Februari 2016.

[6] Ihwan, Andi., 2012, "Penyesuaian Fungsi Deret Fourier untuk Karakteristik Pola Curah Hujan di Kota Pontianak", POSITRON Vol. 2 No. 1 Hal. 29-32.

[7] Agusta, Atang Rahma., 2013, "Pemodelan Curah Hujan Bulanan di Kabupaten Sintang Menggunakan Metode Monte Carlo dengan Algoritma Metropolis", POSITRON Vol. 3 No. 2 Hal. 32-34.

[8] Grandis, Hendra., 2009, "Pengantar Pemodelan Inversi Geofisika", Himpunan Ahli Geofisika Indonesia (HAGI), Bandung.

[9] Sugiyono, 2013, "Statistika untuk Penelitian", Alfabeta, Bandung.

[10]Widiasari, Etty., 2012, "Analisis Konsentrasi Sedimen Melayang di Muara Sungai Kapuas Kalimantan Barat", Universitas Tanjungpura, Program Studi Fisika, Fakultas Matematika dan Ilmu Pengetahuan Alam, Pontianak, (Skripsi). 
[11]http://www.bmkg.go.id/BMKG_Pusat/Geofi sika/Tanda_Waktu/, diakses 20 Oktober 2015. 